\title{
Sangku Mencari Riang: Pertemuan Sangkuriang dan Oidipus dalam Perlawanan terhadap Takdir dan Nasib
}

\author{
Giri Mustika Roekmana ${ }^{1}$ \\ Program Pascasarjana, Institut Seni Indonesia Yogyakarta
}

\begin{abstract}
ABSTRAK
"Sangku mencari Riang" menceritakan pertemuan antara mitos Sangkuriang dari Sunda dan Oidipus dari Yunani Kuno. Cerita ini dibuat sebagai kelanjutan dari cerita rakyat Sangkuriang dengan kisah tragedi Yunani Oidipus Raja karya Sophocles. Cerita yang diciptakan melalui pendekatan intertekstualitas dan interpretasi ini menawarkan makna baru. Cerita ini dibentuk berdasarkan konsep teater rakyat Sunda yang fleksibel dan dinamis dikombinasikan dengan elemen teater Yunani klasik yang melibatkan peran paduan suara dengan kata-kata puitis dalam dialog. Selain itu, penggunaan media dan topeng untuk menyempurnakan karakter menghasilkan estetika bagi penonton. Oleh karena itu, perpaduan konsep antara mitos Sunda dan tragedy Yunani ini memberikan perspektif baru dalam ruang kerja penciptaan seni teater. Hasil kolaborasi dua konsep akan terlihat dalam pertunjukan dengan kekuatan musik, tematik, estetika visual, dan dinamika oral. Dengan cara ini mampu menimbulkan daya tarik bagi para penonton.
\end{abstract}

Kata kunci: cerita rakyat, intertext, mitos Sunda, teater Yunani.

\section{ABSTRACT}

Sangku Looking For Riang Theatre: performances: Sangkuriang meetings and Oedipus in the fight against Destiny and Fate. "Sangku Mencari Riang" is a story which describes the meet of Sangkuriang from Sundanese and Oidipus from Ancient Greek. This story was created as a continuation story of folklore Sangkuriang of Sunda with the story of the Greek tragedy of Sophocles's work, that is Oidipus the King. Through the intertext study, then, a new interpretation of the story was created, and finally the story of "Sangku Mencari Riang" was offered with its new meaning as well. This story will be perfomed to approach the concept of the folk theater of Sundanese which is regarded as fexible and dynamic, and has a dynamic structure. This concept will be combined with some elements found in the classical Greek theater, in which there is a choir role with poetic words in any dialogues on the performance. Moreover, the use of media which gives the impression of refinement masks of the characters and the ritualistic and aesthetic views for spectators are given to this concept as well. Therefore, these two concepts will provide a new perspective in the work space of theatrical arts creation. Then the result of the collaboration between the two concepts will be seen in the performance with musical powers, essential thematic, visual aesthetics, and oral dynamics, and afterward it will be supposed to give rise to any great attraction for the spectators.

Key words: folklore, intertext, Sundanese myth, Greek Theater.

\section{Pendahuluan}

Mengangkat cerita-cerita tentang legenda atau mitos dalam sebuah seni pertunjukan tentu masih memiliki daya tarik untuk disimak, karena cerita legenda atau mitos mengandung nilai-nilai pesan moral yang masih menarik untuk diapresiasi. Mitos yang berkembang di masyarakat sering merupakan wacana atau pendapat pribadi yang disebar luaskan, dan masyarakat diberi kebebasan untuk mempercayainya atau tidak. Roland Barthes (2011:151) mengatakan bahwa mitos merupakan sistem komunikasi yang menyampaikan pesan. Hal ini akan memungkinkan manusia untuk berpandangan bahwa mitos tidak bisa menjadi sebuah objek, konsep, atau ide. Mitos adalah cara penandaan, sebuah bentuk.
Sebuah pesan yang akan disampaikan oleh mitos memiliki nilai-nilai yang menjadi cerminan sekaligus kontrol terhadap sikap dan perilaku manusia baik buruk maupun baik. Bagaimana, misalnya, manusia bersikapi ketika berhadapan dengan persoalan takdir dan nasib. Takdir dan nasib merupakan hakikat hidup manusia dalam proses kehidupannya di dunia. Sering manusia menyebutkan bahwa takdir itu sesuatu yang tidak bisa diubah, sesuatu yang pasti, sesuatu yang telah digariskan oleh Yang Maha Kuasa dan tidak ada yang mampu menentangnya. Begitu pula ketika manusia menyadari bahwa nasib adalah sesuatu yang dialami oleh manusia tetapi masih dapat diubah sesuai dengan keinginan dan kemampuan manusia untuk mengubahnya. 
Tema-tema takdir dan nasib dalam sebuah karya seni, khususnya seni pertunjukan teater, memang masih tetap kontekstual sampai saat ini. Selain itu manusia sebagai mahluk hidup yang menjalani proses kehidupannya berada pada realitas pilihan-pilihan, meskipun sebenarnya ketika manusia tidak memilih, itu adalah sebuah pilihan. Pilihan-pilihan menjadikan manusia pasrah dan menerima apa adanya atau manusia melakukan sebuah perlawanan untuk bisa mengubahnya.

Berangkat dari tema besar tentang takdir dan nasib, terutama pada wilayah 'pilihan-pilihan', yakni pasrah atau melawan sesuai posisi manusia itu berada, maka penulis mencipta sebuah naskah lakon sekaligus pertunjukan teater berjudul Sangku Mencari Riang. Lakon ini akan dijadikan sebagai media transformasi gagasan tentang pilihan-pilihan dan pemberontakan terhadap takdir dan nasib ke dalam realitas pertunjukan.

Cerita Oidipus dan Sang Kuriang memiliki tema besar tentang takdir dan nasib. Serta dua cerita ini berasal dari budaya yang berbeda, Sang Kuriang berasal dari cerita lisan milik rakyat Jawa Barat (Sunda) versi Utuy T. Sontani. Sementara cerita Oidipus berasal dari mitologi Yunani versi Sophocles. Keduanya memiliki persamaan cerita yang sangat menarik untuk diangkat kembali ke dalam sebuah pertunjukan teater. Cerita Oidipus berasal dari mitologi sebagai pemujaan terhadap Dewa Dyonisus. Untuk kebutuhan penciptaan Sangku Mencari Riang ini versi cerita Oidipus menggunakan naskah yang sudah diterjemahkan oleh WS. Rendra, yaitu Oidipus Sang Raja. Dalam cerita ini dikisahkan Oidipus putra Thebes mendapat ramalan bahwa dia suatu saat akan membunuh bapak dan mengawini ibu kandungnya, mengetahui akan ramalan itu maka Oidipus dibuang oleh ayah dan ibunya sejak masih bayi ke hutan, di hutan dia diselamatkan oleh seorang gembala dan diserahkan kepada seorang raja di Corintha. Setelah besar Oidipus mendengar bahwa dia diramalkan akan membunuh bapak dan ibunya, mendengar itu Oidipus pergi meninggalkan Corintha dengan maksud menghindari ramalan tersebut. Di perjalanan dia bertemu dengan peziarah dan terjadi perkelahian, Oidipus membunuh para peziarah itu dan hanya satu orang yang selamat. Setibanya di Thebes yang sedang dilanda bencana, serta diserang oleh monster berkepala perempuan, berbadan singa dan memiliki sayap. Oidipus berusaha memberikan pertolongan pada masyarakat Thebes. Berkat kepintarannya, Oidipus dapat mengalahkan monster itu dan membebaskan rakyat Thebes dari bencana, diangkatlah Oidipus menjadi Raja dan dinikahkan dengan janda raja terdahulu.

Singkat cerita setelah Oidipus menjadi raja Thebes, negeri itu dilanda bencana hebat yang disebabkan oleh adanya seorang pendosa yang telah mengawini ibu dan membunuh bapaknya. Oidipus segera mencari pendosa itu dan ternyata setelah dibuktikan oleh beberapa saksi dapat disimpulkan bahwa pendosa itu adalah Oidipus sendiri. Maka dia menusuk matanya sampai buta dan meminta untuk diasingkan, sementara Jokasta sang ibu sekaligus isterinya mati menggantung diri. Dalam cerita ini terdapat konflik tentang perlawanan, yaitu ketika Oidipus digariskan oleh Dewata bahwa dia akan membunuh bapaknya dan mengawini ibunya, Oidipus mencoba menghindari ramalan dengan pergi mengembara ke negeri lain, walaupun akhirnya ramalan itu tetap terjadi.

Sementara cerita Sang Kuriang versi Utuy T. Sontani mengupas penolakan tentang keturunan orang Sunda adalah binatang, seperti manusia ketahui bahwa dalam cerita rakyatnya dikatakan bahwa ayah kandung Sang Kuriang adalah si Tumang yang berwujud anjing, namun dalam versi Utuy wujud si Tumang yang merupakan ayah kandung Sang Kuriang berwujud orang tua yang memiliki cacat fisik. Dalam versi Utuy ini pun cerita Sang Kuriang terdapat pertanyaan tentang eksistensi Sang Kuriang, benarkah Dayang Sumbi itu adalah ibu kandungnya? Bukti apa yang bisa diungkapkan bahwa Sang Kuriang adalah anak kandung Dayang Sumbi? Ketika Sang Kuriang menolak bahwa sesungguhnya Dayang Sumbi itu adalah ibu kandungnya bahkan sudah mengetahuinya sejak lama, namun dia tetap bersikukuh untuk tetap menikahi Dayang Sumbi. Sang Kuriang adalah sebuah gambaran karakter yang berpegang teguh pada kebenaran yang menurut dia benar. Spirit perlawanan batin Oidipus dan Sang Kuriang ini akan penulis jadikan pijakan idealisme pikiran untuk menciptakan peristiwa baru sebagai peristiwa lanjutan dari cerita sebelumnya yang merupakan proses untuk melakukan perubahan sekaligus menentukan 
takdir dan nasibnya sendiri. Kedua kisah tersebut adalah sebuah kisah yang mengangkat tema besar takdir dan nasib yang sama, sama-sama korban dari permainan para Dewata yang mengharuskan mereka berada pada jalan yang sudah digariskan yaitu, menikahi ibu dan membunuh bapak kandungnya.

Menurut pendapat Soetomo Mangoenhardjo, seperti halnya di daerah lain, manusia Yunani Kuna memiliki naluri kepercayaan bahwa apa yang ada di dunia ini berada dalam pengawasan suatu kekuasaan yang tidak bisa dilihat oleh sembarang orang. Yaitu kekuatan yang mengatur keadaan, gerak, dan sikap hidup manusia, hewan, dan barang lain di alam semesta. Kekuatan yang tidak dapat dilihat oleh sembarang orang itu dalam bahasa Yunani Kuna disebut Theos, bahasa latin Deus. Dua perkataan yang serumpun dengan kata Indonesia Dewa, yang berasal dari suatu bahasa rumpun Indo-Eropa, yaitu Sansekerta (Soetomo Mangoenhardjo, 1976:9).

Dalam penciptaan Sangku Mencari Riang ini, akan dilakukan sebuah kreasi dengan mempertemukan kedua tokoh utama yang berbeda budaya ke dalam sebuah bangunan cerita baru sebagai sebuah perlawanan terhadap cerita sebelumnya (takdir dan nasibnya). Oleh karena cerita Oidipus dan Sang Kuriang ini merupakan kisah yang sudah sangat populer di dunia teater maupun karya sastra secara luas. Kedua tokoh tersebut akan bertemu dan melakukan sebuah pemberontakan sebagai wujud kreativitas dalam penciptaan karya seni teater. Di sinilah proses penciptaan teks dimulai, setelah dilakukan penelusuran terhadap naskah Oidipus karya Sophocles dan Sang Kuriang karya Utuy, maka terciptalah sebuah bangunan cerita baru yaitu Sangku Mencari Riang.

Penulis melakukan sebuah pendekatan intertekstualitas sebagai pondasi karya yang akan diciptakan untuk menopang gagasan yang akan diciptakan. Dalam hal ini penulis mencoba membuat penafsiran baru, cerita baru dalam kaitannya dengan proses kreatif, artinya, bahwa penulis tidak akan membawakan ulang kisah Oidipus dan Sang Kuriang, namun penulis sebagai kreator akan membuat kelanjutan kisah Oidipus dan Sang Kuriang.

Pendekatan intertekstualitas pertama kali diilhami oleh gagasan pemikiran Mikhail Bakhtin, seorang filsuf dari Rusia yang mempunyai minat besar pada sastra. Menurut Bakhtin, pendekatan intertekstualitas menekankan pada kerangka teksteks sastra lain, seperti tradisi, jenis sastra, parodi, acuan atau kutipan (Noor, 2007: 4-5).

Sementara menurut Kristeva (1980: 66), intertekstualitas pada umumnya dipahami sebagai hubungan suatu teks dengan teks lain. Kristeva berpendapat bahwa setiap teks terjalin dari kutipan, peresapan, dan transformasi teks lain. Sewaktu menulis, pengarang akan menggunakan elemen teks yang lain sebagai bahan dasar untuk menciptakan karyanya. Semua disusun dengan beberapa penyesuaian demi mencipta sebuah karya yang baru.

Ideologi kekaryaan akan mengarahkan sikap manusia pada kerja penciptaan. Albert Camus menyatakan bahwa ketika mencipta sebuah karya seni, seorang seniman hendak menghadirkan dunia tidak sebagaimana adanya, tetapi dunia sebagaimana yang dirasakan dan dipahaminya, dunia yang diinginkannya-meskipun absurd. Menciptakan karya seni hakikatnya merupakan pemberontakan terhadap absurditas. Seorang pemberontak adalah seorang yang kreatif (Djelantik, 2002: 25).

Menurut Ajip Rosidi (2009:35) Sang Kuriang adalah gambaran manusia Sunda yang jujur, patuh, pemberontak, dan pemberani, yang memiliki sifat naon naon ku nanaon (apa-apa oleh apapun). Bertolak dari hal tersebut muncul sebuah ide untuk memunculkan sisi lain dari pemikiran Sang Kuriang yang merasa dirugikan oleh Dewata. Secara garis besar, plot cerita berlangsung mulai dari perjalanan Dunia Bawah, ke Dunia Tengah, hingga Dunia Atas. Ide ini dipengaruhi oleh pola pikir budaya mistis orang Sunda. Menurut Jakob Sumardjo (2003: 165), dunia memiliki tingkatan yang terdiri dari Dunia Bawah yaitu dunia manusia, Dunia Tengah yaitu alam gaib, dan Dunia Atas yaitu dunia para Dewa. Dalam kisah Sangku Mencari Riang, mereka melakukan "protes" pada takdir dan nasib atas peristiwa yang dialami mereka, dan melakukan perjalanan spiritual menuju Kahyangan. Kisah Oidipus dan Sang Kuriang adalah sebuah ungkapan dari perlawanan psikologis tokoh terhadap apa yang sudah dialaminya. 


\section{Penciptaan Sangku Mencari Riang}

Penulis lakon sebagai homocreator (istilah yang dipinjam dari Michael Landman) harus mampu memanfaatkan realitas sebagai sumber ilham bagi karya-karyanya. Ia selain memanfaatkan realitas, juga harus melakukan selektivitas ide/gagasan sekaligus melakukan pemamahbiakan (ruminisasi) ide dan gagasan yang diseleksinya, lalu melakukan perenungan. Muaranya sampai menghasilkan pesan (massage) yang ditawarkan sebagai nilai (values) di balik bentuk (Nalan, 1998: 10).

Melalui pendekatan intertekstual, penulis mengambil komponen-komponen cerita Sang Kuriang dan Oidipus yang akan dijadikan komponen bagi penciptaan karya seni pertunjukan. Dari kedua naskah tersebut, komponen yang diambil sebagai dasar penciptaan adalah tokoh utama, yaitu Oidipus dan Sang Kuriang, alur cerita di mana Sang Kuriang mengawini ibu kandungnya dan Oidipus membunuh bapak kandungnya, tema cerita yang berpusat pada perdoalan takdir, nasib, eksistensialisme. Komponen-komponen tersebut akan menjadi konflik yang sekaigus sebagai permasalahan dalam cerita Sangku Mencari Riang. Pertemuan tokoh dalam Sangku Mancari Riang ini terilhami dari cerita pendek berbahasa Sunda yang berjudul Kalangkang Budah, karya Godi Suwarna. Dalam cerita pendek tersebut dikisahkan tentang pertemuan Sang Kuriang yang sedang berada di pinggir laut sedang menghujat Dewata tentang nasibnya yang telah membunuh bapak sekaligus keinginannya untuk menikahi ibu kandung. Pada saat itu Oidipus yang sedang melakukan pelayaran bertemu dan berdialog tentang takdir dan nasibnya yang memiliki kesamaan. Cerita yang akan penulis garap tentu berbeda dengan cerpen Kalangkang Budah tersebut, karya yang penulis ciptakan nanti cakupannya akan lebih luas lagi, yaitu tidak hanya sebatas bertemu dan membahas tentang kesamaan cerita saja tetapi dilanjutkan dengan pernyataan sikap untuk melawan takdir dan nasib dengan cara menemui Sang Takdir dan Nasib untuk meminta suatu perubahan.

Penjelasan dari skema di atas sebagai berikut, seniman sebagai homocreator teater menangkap gagasan dan kegelisahan untuk diekspresikan ke dalam kenyataan pentas melalui khasanah cerita lisan dari dua budaya yang berbeda. Adapun ceritan lisan itu mengambil cerita legenda Sang Kuriang versi Utuy T. Sontani dari Jawa Barat dan cerita Oidipus Sang Raja dari mitologi Yunani Klasik karya Sophocles. A

\section{Skema penciptaan:}



"SANGKU MENCARI RIANG" 


\section{Sumber Ide Penciptaan}

\section{Tema dan Ide}

Kisah ini memiliki tema tentang perlawanan seorang manusia terhadap takdir dan nasibnya. Ketertekanan diri oleh takdir dan nasib yang tidak berpihak menyebabkan manusia berada dalam dua pilihan, yaitu, pasrah atau melawan, pilihan yang diambil untuk karya Sangku Mencari Riang sebagai penopang gagasan yang ingin dicapai dalam penciptaannya adalah perlawanan atau pemberontakan. Ide dasar dari terciptanya karya ini berangkat dari kegelisahan penulis terhadap fenomena takdir dan nasib yang menimpa manusia. Takdir dan nasib memang dua kata yang sulit dipisahkan dan keduanya selalu ada dalam proses perjalanan hidup manusia. Tema ini penulis angkat dalam pertunjukan sebagai sebuah intorspeksi tentang sebuah kesadaran akan proses hidup manusia di dunia ini.

Judul yang dipilih untuk karya penciptaan seni teater ini adalah Sangku Mencari Riang. Sangku Mencari Riang diambil dari nama "Sangkuriang", lalu dibagi dua menjadi "Sangku" dan "Riang” yang di tengahnya ditambah kata "mencari", menjadi "Sangku Mencari Riang". "Sangku” yang artinya "Sang Aku". "Sang Aku" adalah Sangkuriang yang telah menjadi satu fikiran dengan Oidipus yang melakukan sebuah protes pada penciptanya untuk mengubah nasib dan takdir buruk yang menimpa mereka di dalam cerita sebelumnya. Sangku dan Oidipus adalah satu dalam dua, dua dalam satu, menjadi Sangku atau Sang Aku.

Kata "mencari" mengandung makna proses, perjalanan, perjuangan yang dilakukan oleh Sangku dan Oidipus untuk mencapai "Riang". "Riang" adalah kata lain dari ceria, bahagia atau kebahagiaan. Jadi judul Sangku Mencari Riang adalah sebuah proses perjalanan Sangku dan Oidipus dalam usahanya mencapai kebahagiaan dengan cara melakukan protes pada sang pencipta atas nasib buruk mereka di dalam cerita sebelumnya.

\section{Konvensi Teater Rakyat Jawa Barat (Longser)}

Cerita ini akan dibawakan dengan gaya teater rakyat Jawa Barat, yaitu seni Longser. Penciptaan panggung tidak akan membuat seni pertunjukan Longser secara utuh, tetapi hanya meminjam idiom-idiom yang seringkali ada dan khas dalam
Longser. Seni Longser adalah seni yang dinamis, ringan, dan mudah untuk diolah secara kreatif. Peluang-peluang eksplorasi bentuk terbuka untuk menembus ruang yang tanpa batas.

Menggarap naskah tragedi dengan pembawaan yang lebih ringan dan longgar kiranya akan lebih menarik dan menjadi paradoks. Seni Longser adalah sebuah bentuk kesenian teater rakyat dari Jawa Barat yang mengandung unsur nyanyian, tarian, musik, lakon, dan perupaan (seni rupa/ artistik). Struktur Longser bisanya dimulai dengan tatalu (overture), rajah (do'a), ronggeng (tarian), lakon atau cerita dan penutup (rajah pamunah). Unsur bobodoran (lawakan) biasanya sangat dominan dan berfungsi sebagai hiburan rakyat untuk mengisi waktu senggang. Selain itu, ciri khas Longser sangat terbuka luas dalam pengembangan ruang-ruang imajinatif, misalnya, apapun bisa diciptakan menjadi "sesuatu" atau apa saja. Instrumen kendang bagi pemain Longser bisa jadi meja, mobil, motor atau apa saja. Bahkan tubuh mereka sendiri bisa dibuat menjadi apa saja sesuai dengan tuntutan kebutuhan cerita. Bahkan pergantian adegan pun bisa mereka lakukan dengan sangat naif, misalnya seorang tokoh hendak pergi ke Jakarta dari Bandung, mereka hanya berjalan mengelilingi panggung satu putaran lalu diam sambil berucap "wah sudah sampai lagi di Jakarta...”. Mereka melakukannya tanpa pergantian setting, tapi perubahan ruangnya sangat terasa sekali, para pemain, pemusik, tidak ada yang ke luar dari arena panggung. Mereka diam di tempat sambil menyaksikan para tokoh menjalankan alur cerita di panggung.

Gaya pertunjukan teater Longser menarik jika diterapkan ke dalam pertunjukan Sangku Mencari Riang ini, karena kemasan seperti ini bisa menjadi paradoks dengan cerita yang sesungguhnya. Cerita Oidipus adalah naskah tragedi, cerita Sang Kuriang adalah naskah dengan tingkat ritualitas yang tinggi. Pada saat cerita tragedi yang memiliki nuansa ritus yang tinggi dibawakan dengan pemanggungan yang ringan pasti akan tercipta suasana yang baru yang unik dan menarik. Selain itu, sangat memungkinkan bisa memasukkan atau mengadopsi bentuk kesenian lain untuk diterapkan di dalam pertunjukan ini.

\section{Konvensi Teater Yunani Klasik}

Semua konvensi dalam teater Yunani menunjukkan suatu perancangan yang sangat 
baik. Naskah dinyanyikan dan ditarikan, maka manusia berhadapan dengan gaya pertunjukan yang berbeda dengan pertunjukan masa kini. Kesemuanya itu menunjukkan kebenaran alami yang menjadi titik tekan orang-orang Yunani. Apa yang dilakukan kelompok sebagai pertunjukan teatrikal yang efektif tergantung keakraban dan pemahaman kelompok tersebut pada sederetan konvensi serta keterampilan yang menyebabkan konvensi tersebut terwujud (Yudiaryani, 2002: 54).

Teater Yunani klasik adalah sumber dan dasar kehadiran teater di Barat. Catatan pertama yang berhasil ditemukan adalah tahun 534 B.C. ketika suatu festival melahirkan tragedi pertama terbaik. Pemenang kontes tragedi pada festival itu adalah Thespian, penulis drama dan aktor pertama yang manusia kenal sekarang ini. Dari namanya itulah istilah Thespian muncul untuk menyebut pemain. Dari awal mulanya drama Yunani ditampilkan secara ekslusif pada festival untuk merayakan Dionysus, yang merupakan salah satu Dewa yang paling dihormati masyarakat Yunani. Di dalam konvensi yang ada dalam teater Yunani klasik biasanya terdiri dari penggunaan topeng, koor dan tarian, nyanyian puja.

\section{Perwujudan dan Pemanggungan}

Bentuk lakon Sangku Mencari Riang ini menggunakan pendekatan tragedi sebagai pendalaman peristiwa yang akan diwujudkan di atas panggung. Konsep tragedi memiliki tiga aspek sebagai pusat pemahaman peristiwa di atas pentas, ketiga aspek itu antara lain: aspek estetika, aspek kejiwaan, aspek filosofis (Bakdi Sumanto, 2001: 170). Ada tiga pertanyaan yang harus diajukan untuk mempertajam konsep tragedi yaitu, apa hubungan manusia dengan alam, dirinya sendiri, dan sorga? Bagaimana manusia bisa sekaligus jadi makhluk yang mempunyai kebebasan (free will) dan menjadi bagain dari masyarakat dan alam semesta? Apa makna pilihan atas perbuatan jahat dan penderitaan yang menjadi konsekuensinya? Jika ketiga pertanyaan itu diajukan, manusia akan tergetar hatinya secara mendalam karena melihat lakon tragedi. Mereka memperoleh pemahaman bahwa jika bagian pertama lakon itu memperkuat kesadaran akan suatu pemberontakan, bagian akhir lakon mendamaikan si pemberontak dengan rahasia atau misteri yang ada di jantung alam semesta.
Lakon Sangku Mencari Riang merupakan lakon tragedi karena tokoh utama mengalami peristiwa tragis, yaitu ketika Sangku dan Oidipus akan melakukan protes kepada Dewata dengan segala daya dan upaya serta kegigihannya yang tidak terbendung. Namun demikian, protes tetap kandas karena mereka sudah mengalami takdir yang tidak bisa diubah lagi lantaran peristiwa yang mereka alami di masa lalu sebenarnya sudah terjadi dan tidak mungkin untuk diubah.

Konsep pemanggungan pertunjukan naskah Sangku Mencari Riang ini menggunakan pendekatan pertunjukan Yunani klasik. Gaya ini tidak lepas dari nuansa ritual yang masih erat kaitannya dengan upacara keagamaan pemujaan pada Dewa Dyonisus. Dipadu dengan gaya pertunjukan teater rakyat Jawa Barat, pertunjukan ini akan menghasilkan bentuk pertunjukan yang dinamis, ringan, musikal, puitis, tanpa meninggalkan unsur ritual yang dikemas dengan unsur nyanyian, dialog, kor dan tarian. Kedua gaya ini akan penulis gabungkan, sehingga akan menghasilkan gaya pemanggungan yang baru. Maka secara visual pementasan ini akan menunjukkan kekhasan pertunjukan Yunani klasik dan akan menampilkan kekhasan Sunda.

Spirit pertunjukan pun akan berdekatan ddengan gaya Brecht, yakni gaya alinasi dan epik akan terlihat meskipun tidak secara total. Brecht menggunakan konsep alinasi yaitu memisahkan penonton dari peristiwa panggung, sehingga mereka melihat panggung dengan kritis. Brecht mengingatkan penonton akan fungsi utama media panggung. Cahaya dibiarkan apa adanya, pemusik diletakkan di atas panggung. Aktor terkadang ke luar dari perannya serta berdialog dengan penontonnya. Brecth biasanya menerapkan konsep pada aktornya untuk menampilkan karakter dan tidak menjadi karakter (Ipit S. Dimyati, 2010:19). Kegiatan eksplorasi bentuk dengan eksperimeneksperimen di dalam proses teater menjadi lahan yang cukup luas dilakukan penulis ketika menggarap naskah Sangku Mencari Riang ini. Pengolahan tubuh yang meminjam gerak-gerak tari menjadi semacam media kreatif dalam membuat penggambaran visual pada setiap adegannya dan memberikan komposisi ruang imajinasi yang tanpa batas penafsiran bagi penontonnya.

Unsur nyanyian akan menjadi dialog perenungan bagi penonton sehingga akan terbawa ke sebuah 
kesadaran jiwa untuk membuka cakrawala berpikir tentang kehidupan manusia. Dialog-dialog yang diungkapkan secara bersamaan (kor) akan penulis hadirkan sebagai sebuah ungkapan keberagaman sekaligus perbedaan pandangan hidup manusia tentang nasib dan takdir, gaya ungkapnya akan menjadi spektakel yang memberikan teror psikologis pada penonton. Seperti halnya di dalam naskah karya Arifin C. Noer yang berjudul Madekur dan Tarkeni yang merupakan bagian dari episode Orkes Madun keempat terdapat dialogdialog bersamaan yang menggambarkan suatu adegan yang berbeda peristiwa namun dilakukan dalam suatu waktu, lakon ini juga memberikan semacam inspirasi bagi terciptanya adegan-adegan rampak dalam naskah Sangku Mencari Riang ini.

Konsep pertunjukan yang meminjam beberapa unsur seni yang lainnya dalam pertunjukan Sangku Mencari Riang ini tentu saja akan menjadikan pertunjukanyangdinamisdan efektifsertamenjurus ke arah inovasi. Konsep artistik adalah bagian yang cukup vital di dalam proses pemanggungan sebuah pertunjukan untuk menunjang pada wilayah komunikasi estetik secara visual dengan penontonnya. Konsep yang digunakan di dalam pemanggungan lakon Sangku Mencari Riang adalah sebagai berikut, panggung terdiri dari tiga bagian yaitu panggung satu digunakan sebagai ruang peristiwa dunia nyata atau dunia manusia, ruang peristiwa ini menggunakan area penonton yang ditata sedemikian rupa hingga membentuk panggung peristiwa, sementara penonton berada di sisi kiri dan kanan area tersebut. Di panggung prosenium terdapat material bambu yang dijadikan batas garis undakan panggung sebagai sebuah gambaran dunia yang memiliki tahapan-tahapan kehidupan manusia di dunia, yaitu kelahiran proses kehidupan dan proses kematian.

Panggung dua digunakan sebagai ruang khayalan sebagai manifestasi perlawanan Sangku dan Oidipus terhadap takdir dan nasib yang sudah dijalaninya di masa silam, di panggung dua ini tidak terdapat material artistik tapi hanya menggunakan level yang dibungkus kain hitam sebagai gambaran dunia imajinasi, khayalan di dalam alam pikiran manusia. Area yang digunakan terdapat di depan panggung prosenium tepat di tengah-tengah antara panggung area penonton dengan panggung prosenium tersebut. Sementara


Gambar 1. Tata panggung

panggung tiga adalah ruang peristiwa dialog antara Sangku dan Oidipus dengan Sang Entah sebagai gambaran dari Dewata yang mengendalikan manusia atas takdir dan nasibnya itu.

Panggung tiga menggunakan panggung prosenium yang terdapat bambu yang berdiri segi tiga menjulang ke atas dibungkus kain putih sebagai simbol transenden yang memiliki kaitan dengan sang pencipta atau ke-Dewa-an di kahyangan. Gedung pertunjukan yang sebenarnya adalah gedung pertunjukan proscenium yang penontonnya hanya dapat melihat dari arah depan saja, namun oleh penggarap di buat menjadi tiga area panggung yang sudah dijelaskan di atas dengan alasan untuk menciptakan ruang yang berbeda, nuansa yang berbeda, menciptakan ruang imajinasi yang berbeda untuk menguatkan karakter pertunjukan yang dinamis, 
inovatif dan kreatif. Selain itu juga untuk lebih mengakrabkan dengan penonton yaitu jarak yang lebih dekat antara ruang peristiwa dengan tempat duduk penonton terutama di babak satu yang menggunakan area panggung satu.

Sementara kostum yang digunakan adalah kostum dengan pendekatan kostum Yunani dan kostum Sunda. Keduanya dikolaborasi dalam satu kesatuan, dan penonton akan dapat mendeteksi secara visual bahwa yang diguanakan terdapat ornamen-ornamen yang khas ada di dalam kostum kedua kultur tersebut (Yunani dan Sunda). Sementara kostum yang dipakai oleh tokoh "Sang Kelana" dan "Sang Entah" merupakan kostum denga pendekatan kekinian. Kostum tersebut menjadi gambaran pikiran-pikiran modern yang masuk ke dalam ranah lakon cerita rakyat masa lalu. Secara filosofis, pikiran-pikiran di masa lalu akan tetap ada dan terjadi di masa kini maupun di masa yang akan datang.

Penggunaan topeng yang dipakai oleh setiap tokoh merupakan penegasan karakter dan kamuflase ekspresi karakter tokoh yang dapat memunculkan efek magis, namun tetap menjadi dinamis seiring penerapan pola permainan akting yang longgar. Karakter tokoh keluar masuk peran sesuai dengan kebutuhan suasana yang diciptakan. Karakter tokoh terkadang lepas dan menjadi karakter pemerannya sendiri dengan membuka topengnya tersebut.

Konsep musik yang akan digunakan adalah perpaduan antara musik khas Yunani yang akan dikolaborasi dengan musik khas Jawa Barat (Sunda). Alat musik yang akan digunakan meliputi: Kecapi, Kendang, Suling bambu, Terbangan, Pianika, Chelophone, Genjring, dan beberapa alat perkusi (alat buatan sendiri). Selain alat musik ada juga vokal yang terdiri dari vokal beluk, yaitu suara melengking khas seni tradisional Jawa Barat sebagai penanda identitas lokal ke-Sunda-an dan vokal seriosa, yakni suara melengking yang biasa digunakan dalam orkestra, namun mengalami distorsi seiring kebutuhan pentas dalam menciptakan ruang imajinasi sebagai penggambaran khas Yunani. Alat musik yang akan digunakan meliputi: Kecapi, Kendang, Suling bambu, Terbangan, Pianika, Chelophone, Genjring, dan beberapa alat perkusi (alat buatan sendiri).

\section{Penutup}

Pada saat tradisi lisan menjadi sumber, maka identitas cerita lisan tidak lagi berbicara hanya di sekitar pemiliknya, tetapi juga bersinggungan dengan nilai-nilai budaya dari penikmatnya yang lain. Lakon Sangku Mencari Riang adalah lakon bersumber dari cerita mitos dan legenda yang merupakan tradisi lisan. Tentu saja suatu hal yang positif ketika menggarap naskah yang bersumber dari cerita rakyat baik mitos maupun legenda, karena manusia sampai kapanpun tidak akan lepas dari masa lalu yang senantiasa berkaitan dengan masa kini maupun masa depan, dalam hal ini adalah proses perjalanan hidup manusia.

Pertunjukan yang memanfaatkan semua konvensi pertunjukan yang sudah ada dan diterima oleh masyarakat serta diberi nuansa yang baru atau mungkin lain sama sekali adalah sebuah proses eksplorasi yang tidak ada habis-habisnya. Pencapaian pada sebuah pertunjukan yang baru tentu saja harus terus dilakukan sebagai suatu proses kreatif yang terus berkembang sehingga masyarakat akan menilainya sebagai sebuah kelestarian gagasan seni yang seirama dengan perkembangan zaman saat ini. Pertunjukan teater Sangku mencari Riang ini disarankan dapat dimanfaatkan sebagai dasar atau pola yang perlu dikembangkan untuk menemukan satu kebaruan dari pertunjukan teater.

Lakon Sangku Mencari Riang merupakan seni pertunjukan teater yang di dalamnya terdapat beberapa unsur seni, seperti seni suara, seni musik, seni tari, seni rupa, dan seni drama, yang digarap sedemikian rupa sehingga menghasilkan pertunjukan teatrikal yang penuh kreativitas, eksplorasi dan inovasi. Lakon ini juga tercipta untuk merespons gejolak masyarakat saat ini, yaitu ketika masyarakat kehilangan kendali diri dalam menghadapi hidupnya. Proses pencapaian kebahagiaan hidup yang sulit didapat menyebabkan manusia memberontak dan bangkit melakukan sebuah perubahan dengan melakukan perlawanan atas takdir dan nasibnya. Takdir memang tidak bisa diubah lagi karena itu merupakan proses yang sudah digariskan oleh sang pencipta sementara nasib masih mungkin untuk diubah karena nasib masih berkaitan dengan sikap dan perilaku manusia itu sendiri dalam menjalani proses kehidupan. Lakon Sangku Mencari Riang 
ini juga diciptakan sebagai sebuah pertunjukan teater yang mencoba membangun nilai-nilai yang sudah kuna tetapi juga menjadi cermin sebuah akulturasi dan pembebasan diri dari kemacetan tata nilai kemanusiaan.

\section{Kepustakaan}

Anirun, Suyatna. 2001. Menjadi Sutradara. Bandung: STSI Press.

Barthes, Roland. 2011. Mitologi. Yogyakarta: Kreasi Wacana.

Durachman. C, Yoyo. 2008. Perkembangan Konsep Penyutradaraan (Bentuk dan Isi). Bandung: Kelir.

Dimyati, S. Dimyati. 2010. Komunikasi Teater Indonesia. Bandung: Kelir.

Djelantik. 1999. Estetika Sebuah Pengantar. Bandung: MSPI.

Ekajati, Edi. 1995. Kebudayaan Sunda: Suatu Pendekatan Sejarah. Jakarta: Pustaka Jaya.

Fergusson, Francis. 1952. The Idea of A Theatre. New York: Mentor Books.

Kristeva, Julia. 1980. Desire in Language a Semiotic Approach to Literature and Art. Oxford: Basil Blackwell.
Mangoenhardjo, Soetomo. 197). Mitologi YunaniRomawi. Bandung: Tarate.

Nalan, Arthur S. 1998. "Mencipta Teater". Dalam Sebuah Pengantar Memahami Teater dan Antologi Naskah lakon. Bandung: Geger Sunten.

Pavis, Patrice. 199), Theatre at the Crossroads of Culture, terj. Loren Kueger London: Routledge.

Rosidi, Ajip. 2009. Manusia Sunda. Jakarta: Kiblat.

Saini KM. 2000. “Teater Indonesia Sebuah Perjalanan dalam Multikulturalisme" dalam Nur Sahid (ed) Interkulturalisme (dalam) Teater. Yogyakarta: Yayasan Untuk Indonesia. Sahid, Nur. 2000. Interkulturalisme (dalam) Teater. Yogyakarta: Yayasan Untuk Indonesia.

Sumardjo, Jakob. 200). Simbol-Simbol Artefak Budaya Sunda Tafsir-Tafsir Pantun Sunda. Bandung: Kelir.

Soemanto, Bakdi. 200). Jagat Teater. Yogyakarta: Media Pressindo.

Yudiaryani. 2002. Panggung Teater Dunia Perkembangan dan Perubahan Konvensi. Yogyakarta: Pustaka Gondosuli. 